Revista Brasil. Bot., V.33, n.1, p.107-113, jan.-mar. 2010

\title{
Pollination and fruit set in pumpkin (Cucurbita pepo) by honey bees
}

\author{
MARIA DAS GRAÇAS VIDAL ${ }^{1,5}$, DAVID DE JONG ${ }^{2}$, HANS CHRIS WIEN ${ }^{3}$ and \\ ROGER A. MORSE ${ }^{4}$
}

(received: May 20, 2009; accepted: February 03, 2010)

\begin{abstract}
Pollination and fruit set in pumpkin (Cucurbita pepo) by honey bees). Species of Cucurbitaceae are cultivated worldwide and are depend on bee pollination for fruit set. Field and lab experiments were conducted at Cornell University, Ithaca, NY, during 1996 and 1997 to determine "Howden" pumpkin (Cucurbita pepo L.) pollen removal and deposition by honeybees and factors relating to male flower attractiveness. Several parameters were evaluated in flowers at anthesis: (1) removal of pollen from anthers by honey bees, (2) pollen deposition on the stigma by honey bees, (3) amount of pollen on the body of honey bees, (4) fruit set after bee pollination, and (5) male flower nectary's pores and flower attractiveness. Honey bees carried between 1,050 to 3,990 pollen grains and 13,765 were removed from an anther after one visit. The amount of pollen deposited on the stigma by the honey bees varied according to the number of visits, from 53 grains with one visit, to 1,253 grains with 12 visits, and the mean number of grains in each visit varied from 53 to 230 grains. The percentage of established fruits was higher $(100 \%)$ when the flowers received 12 visits of Apis mellifera, corresponding to a load 1,253 pollen grains. The attractiveness of the male flower for pollen and nectar collection was increased by the degree of opening of the access pore to the nectary in the flower.
\end{abstract}

Key words - Apis mellifera, bee attractiveness, nectary pore, pollen deposition

RESUMO - (Polinização e estabelecimento de fruto em abóbora (Cucurbita pepo) por abelhas). Espécies de Cucurbitáceas são cultivadas mundialmente e são dependentes de abelhas para polinizacão e estabelecimento de fruto. Experimentos de campo e laboratório foram conduzidos na Universidade de Cornell, na cidade de Ithaca, em Nova York, durante os anos de 1996 e 1997 para determinar a remoção e deposição de pólen por abelhas em abóbora (Cucurbita pepo L.) variedade Howden e fatores relacionados com atratividade da flor masculina. Vários parâmetros foram avaliados depois da antese da flor: (1) remoção de pólen das anteras por abelhas, (2) deposição de pólen no estigma por abelhas, (3) quantidade de pólen no corpo das abelhas, (4) estabelecimento de frutos depois da polinização por abelha, e (5) atratividade da flor masculina via poros nectaríferos. Com uma visita as abelhas removeram 13.765 grãos de pólen, ficando no corpo entre 1.050 a 3.990 grãos. A quantidade de pólen depositada no estigma pelas abelhas variou de acordo com o número de visitas, de 53 grãos com uma visita, para 1.253 grãos com 12 visitas, e o número médio de grãos em cada visita variou de 53 a 230 grãos. A porcentage de frutos estabelecidos foi máxima (100\%) quando as flores receberam 12 visitas de Apis mellifera, correspondendo a uma carga de 1.253 grãos de pólen. A atração da flor masculina por pólen e néctar foi aumentada pelo grau de abertura do poro do néctario da flor.

Palavras-chave - atratividade das abelhas, poro nectarífero, deposição de pólen, Apis mellifera

\section{Introduction}

Pumpkins are a major crop in the Northeast US that depends on honey bees for pollination. Since 1989, bee colonies of $A$. mellifera have been reduced by more than $50 \%$ by chalkbrood fungus (Ascosphera apis), tracheal mite (Acarapis woodi), varroa mites (Varroa jacobsoni) (Morse 1994) and colony collapse disorder (Ragsdale 2007). In order to manage pumpkin

\footnotetext{
1. Universidade Federal da Bahia, Departamento de Zootecnia, Escola de Agronomia, 44380-000 Cruz das Almas, BA, Brazil.

2. Universidade de São Paulo, Departamento de Genéetica da Faculdade de Medicina, Ribeirão Preto, SP, Brazil.

3. Cornell University, Department of Fruit and Vegetable Science, Ithaca, NY, USA.

4. Cornell University, Department of Entomology, Ithaca, NY, USA, deceased.

5._Corresponding author: mgvidal@ufba.br
}

production effectively, it is necessary to know how many bee visits are required for adequate fruit set and fruit size, and the conditions under which fruit set is limited by factors other than pollen. The low fruit set can be due to a lack of honey bees, or to some biotic or abiotic stresses. Unfavorable environmental conditions such as high temperatures, drought and low irradiance can cause the abortion of flower buds in pumpkin and other crops (Wien 1997). The absence of sufficient pollinators can result in low fruit yield and reduced fruit size (Walters $\&$ Taylor 2006). Therefore, to properly manage pumpkin production, it is necessary to know the required number of visit for adequate fruit set and size, as well as conditions that limit fruit set besides the lack of pollen.

Stephenson et al. (1988) found lower fruit set, fruit growth rate and fruit size in zucchini, from flowers treated with low and medium pollen load (240 and 480 pollen grains) than the fruits resulting from flowers 
with high pollen load or free visitation. Nicodemo et al. (2009) reached highest fruit set level when the number of visit by Apis mellifera was 16 per female flower of pumpkin. Although pumpkin fruit set will occur with natural pollinators, the addition of honey bee colonies will ensure the presence of pollinators, to maximize fruit size (Walters \& Taylor 2006)

The specific objectives of this work were: (a) determine the amount of pollen removed from anthers after different number of bee visits and the amount of pollen collected per bee at different periods of the day; (b) Estimate the number of pollen grains deposited on the stigma by honey bees; (c) Relate pollination and fruit set of the pumpkin to pollen load on the stigma, and (d) evaluate the influence of the male flower nectary's opening on the flower's attractiveness to honey bees.

\section{Materials and methods}

Experiments were carried out in 1996 and 1997 at Cornell University, Ithaca, NY (USA). "Howden" pumpkin (Cucurbita pepo L.) were sown in trays with $100 \mathrm{~cm}^{3}$ individual cells, filled with 2:1 (v/v) vermiculite:peatmoss, supplemented with nutrients and maintained in a greenhouse. Twenty days after sowing, the plants were transferred to a field, which had previously been fertilized with $100 \mathrm{~kg} \mathrm{ha}^{-1}$ of nitrogen as urea. The spacing was $2.00 \mathrm{~m}$ between rows by $0.30 \mathrm{~m}$ between plants, giving a density of 16,666 plants per hectare. In 1996, 75 plants were cultivated in an area of $45 \mathrm{~m}^{2}$, and in 1997, 100 plants were planted in $60 \mathrm{~m}^{2}$. A honey bee colony was placed at the edge of the field. Flowers were randomly selected before anthesis and bagged with a net to prevent visits from honey bees and other insects. At anthesis, they were uncovered and the studies described below were performed.

Pollen removed from anther by bees - In this experiment the number of pollen grains removed from anthers by honey bees in different numbers of bee visits was determined on different days, according to Vidal et al. (2006). Male flowers were bagged prior to anthesis and uncovered after anthesis to allow bee visits. Six treatments (number of visits) were evaluated: no visit (remained bagged after anthesis $=$ control), 1, 2, 4, 6, and 8 visits in three replications (flowers) per treatment. After visiting, the anthers were cut off and placed in vials with $70 \%$ ethanol. The anthers were washed with ethanol until all pollen grains were removed. The pollen grains were decanted and the supernatant was removed by micropipet. Glycerol $50 \%$ was added to the remaining pollen in a graduated vial to make up $5 \mathrm{~mL}$. The vials were shaken by a vortex mixer in order to get a uniform pollen suspension. Five samples of $50 \mathrm{uL}$ were taken from the pollen suspension and all pollen grains were counted under $60 \mathrm{X}$ magnification. Total number of pollen grains per anther (in $5 \mathrm{~mL}$ ) was estimated based on the amount of pollen counted in all subsamples
$(50 \mu \mathrm{L} \times 5=250 \mu \mathrm{L})$. This evaluation was performed in 1996 (29 July to 22 August).

Pollen on bee body - The amount of pollen adhering to the body of honey bees was evaluated at $7 \mathrm{~h} 00,8 \mathrm{~h} 00,9 \mathrm{~h} 00$ and $10 \mathrm{~h} 00 \mathrm{am}$ Six honey bees were collected in the field, just after their visit to a flower. Each flower was bagged before anthesis and uncovered after anthesis to allow just one visit of the collected bees. The collected bees were put in tubes with $70 \%$ ethanol and washed until all the pollen was removed from the bees' bodies and counted. The evaluations were performed from 26 to 31 August 1997.

Pollen deposition on stigma - This experiment was conducted between $3^{\text {rd }}$ and $21^{\text {st }}$ August, 1996. Three treatments were evaluated (1,2, and 4 bee visits on stigmas). Twelve female flowers were bagged prior to anthesis (four flowers per treatment) and uncovered after anthesis to allow bee visits according to treatments, in the period from $8 \mathrm{~h} 00$ to $10 \mathrm{~h} 00 \mathrm{am}$ Another experiment was conducted between July $29^{\text {th }}$ and August $15^{\text {th }}, 1997$. Four treatments were evaluated $(2,4,8$, 12 bee visits on stigmas). Twenty-four female flowers were bagged prior to anthesis (six flowers per treatment) and exposed after anthesis. After the different number of visits, the uncovered flowers were cut off and placed in individual vials and frozen. The stigmas were thawed and the pollen grains washed and counted under a $60 \mathrm{X}$ magnifier without staining. The pollen grains remaining on the stigma were removed with a needle probe and also counted.

Pollination and fruit set - In this experiment pistillate flowers were bagged prior to anthesis and uncovered after anthesis to allow 2, 4, 8, and 12 visits (4 levels), using 20 flowers for each level. These visits were permitted from $8 \mathrm{~h} 00$ to $10 \mathrm{~h} 00 \mathrm{am}$ daily on August 6 to 10,14,15,19, 26, and 27, 1997. Only one flower per plant was pollinated and flowers were randomly assigned to treatments in a completely random design. After each visit the flowers were bagged, labeled, and fruit set was evaluated 5 days after pollination when differences in ovary swelling or abscission were obvious. Fruits were removed after fruit set evaluation (8 days after pollination).

Opening of nectaries and attractiveness - This experiment evaluated 32 staminate flowers during 8 days (4 flowers per day). On each day four flowers were surgically manipulated to enlarge the nectary slit to different widths $(0,1,2$, and $3 \mathrm{~mm}$ ). Each flower was placed with pedicel in a vial of water within the pumpkin planting during a 15 -min interval between 7h00-8h00 am, 8h00-9h00 am, or 9h00-10h00 am So, in a 1-hour interval all four flowers were observed during 15 minutes. The number of honey bee visits and the duration of each visit were determined.

\section{Results and discussion}

Pollen removal from anthers by honey bees - Of the nearly 43,000 pollen grains produced by male pumpkin 
flowers in 1996, honey bees removed nearly two thirds with the first two visits and with eight visits, honey bees had taken away nearly $90 \%$ of the total pollen (table 1 ). Considering the short period of anthesis in pumpkin (6 to $12 \mathrm{~h}$ ), the efficient pollen removal in the first visits is advantageous for pumpkin. It may be related to flower morphology, with anthers well exposed to pollinators (Nepi \& Pacini, 1993), increasing the contact probability between insect and anther. In studies with six species, Harder (1990) confirmed that pollen removal is more efficient when anthers are well exposed. The influence of flower morphology on the pollen transfer was also verified by Nilsson (1988) and Murcia (1990), who emphasized that flower morphology can affect pollen removal more than pollen deposition on the stigma. Besides the favorable location of anthers in C. pepo, pollen removal was also facilitated by its large stamens and big and abundant pollen (Free 1993, Harder 1990, Murcia 1990). Honey bees forage on one trip for only pollen or nectar, depending on the flower species and availability of its pollen and nectar. In this work the duration of honey bee visits varied without pattern. This behavior has been found other experiments (Free, 1993)

Pollen on the bee body - The average number of pollen grains adhering to the body of the bee was high early in the day (4,000 grains), declining as pollen was removed from flowers to 1,000 grains by $9 \mathrm{~h} 00$ am (figure 1). The bees visit begins soon after uncovering the male flowers of pumpkin and reached the maximum at $8 \mathrm{~h} 00 \mathrm{am}$. Similar results were recorded on pumpkin by Cady (1993) and Nicodemo et al. (2009). During the visit the bees land on reproductive plant parts and remove pollen grains. The hairs on the bee body brush the anthers and pollen adheres to them. When pollen is abundant the bees that carry more pollen grains are those that visit the flower first, behavior also observed by Nepi \& Pacini (1993). This allow bees gathering more pollen at $8 \mathrm{~h} 00$ am than at later hours in the morning, where decrease of the number of pollen was observed (figure 1).

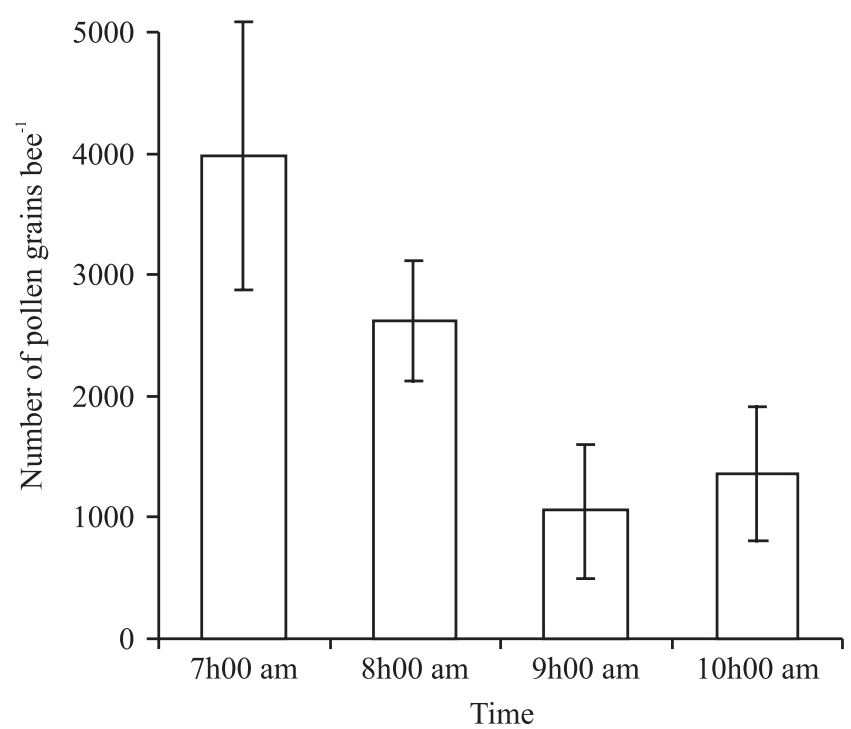

Figure 1. Number of pumpkin pollen grains adhering to the body of bees at different times of the day. Average of six bees, 1997. Bars represent standard deviation.

Pollen deposition on stigma - Bees deposited from 53 to 230 pollen grains per visit, and the duration of each bee visit varied from 18 to 82 seconds (table 2). In 1996, the average number of pollen grains deposited on the stigma by one bee visit was 53, increasing to 918 grains after four visits. In 1997, the number of grains deposited increased from 174 (after 2 visits) to 1,253 (after 12 visits).

Honey bees deposit pollen on the stigma when they collect nectar in the base of the female flower. They removed 13,765 pollen grains in the first visit to male flowers (table 1), which is much larger than

Table 1. Pollen removal activities by honey bees in male pumpkin flowers. Average of four replications, 1996.

\begin{tabular}{|c|c|c|c|c|c|}
\hline \multirow{2}{*}{$\begin{array}{l}\text { Number } \\
\text { of visits }\end{array}$} & \multirow{2}{*}{$\begin{array}{l}\text { Number of pollen } \\
\text { grains in the anther }\end{array}$} & \multirow{2}{*}{$\begin{array}{l}\text { Number of removed } \\
\text { pollen grains }\end{array}$} & \multirow{2}{*}{$\begin{array}{l}\text { Pollen grains } \\
\text { removed per visit }\end{array}$} & \multicolumn{2}{|c|}{ Time (s) } \\
\hline & & & & Total & Per visit \\
\hline 0 & $42,765 \mathrm{a}$ & 0 & 0 & 0 & 0 \\
\hline 1 & $29,000 \mathrm{~b}$ & $13,765 \mathrm{c}$ & $13,765 \mathrm{a}$ & $12 \mathrm{c}$ & $12 \mathrm{~b}$ \\
\hline 2 & $17,245 \mathrm{c}$ & $25,520 \mathrm{~b}$ & $12,760 \mathrm{a}$ & $84 \mathrm{c}$ & $42 \mathrm{a}$ \\
\hline 4 & $8,660 \mathrm{~d}$ & $34,105 \mathrm{a}$ & $8,526 \mathrm{~b}$ & $217 b$ & $54 \mathrm{a}$ \\
\hline 6 & $10,205 \mathrm{~cd}$ & $32,560 \mathrm{a}$ & $5,427 \mathrm{bc}$ & $272 b$ & $45 \mathrm{a}$ \\
\hline 8 & $4,365 \mathrm{~d}$ & $38,400 \mathrm{a}$ & $4,800 \mathrm{c}$ & $443 \mathrm{a}$ & $55 \mathrm{a}$ \\
\hline CV (\%) & 18.2 & 20.9 & 29.3 & 29.8 & 35.4 \\
\hline
\end{tabular}

Means followed by different letters in columns are different (Tukey test, $P<0.05$ ). 
Table 2. Pollen deposit activities by honey bees on female pumpkin flowers. Average of four and six replications in 1996 and 1997, respectively.

\begin{tabular}{cccccc}
\hline Year & Number of visits & $\begin{array}{c}\text { Total time } \\
(\mathrm{s})\end{array}$ & $\begin{array}{c}\text { Pollen grains deposited } \\
\text { (total number) }\end{array}$ & $\begin{array}{c}\text { Time per visit } \\
(\mathrm{s})\end{array}$ & $\begin{array}{c}\text { Number of pollen grains } \\
\text { deposited per visit }\end{array}$ \\
\hline 1996 & 1 & $18 \mathrm{c}$ & $53 \mathrm{~b}$ & $18 \mathrm{~b}$ & $53 \mathrm{~b}$ \\
& 2 & $136 \mathrm{~b}$ & $396 \mathrm{~b}$ & $68 \mathrm{a}$ & $198 \mathrm{a}$ \\
& 4 & $329 \mathrm{a}$ & $918 \mathrm{a}$ & $82 \mathrm{a}$ & $230 \mathrm{a}$ \\
1997 & $\mathrm{CV}(\%)$ & 25.6 & 40.7 & 23.4 & 44.7 \\
& 2 & $134 \mathrm{c}$ & $174 \mathrm{~b}$ & $67 \mathrm{a}$ & $87 \mathrm{a}$ \\
& 4 & $314 \mathrm{bc}$ & $479 \mathrm{~b}$ & $79 \mathrm{a}$ & $84 \mathrm{a}$ \\
& 8 & $643 \mathrm{ab}$ & $668 \mathrm{~b}$ & $80 \mathrm{a}$ & $104 \mathrm{a}$ \\
& 12 & $821 \mathrm{a}$ & $1,253 \mathrm{a}$ & $68 \mathrm{a}$ & 48.3 \\
\hline
\end{tabular}

Means followed by different letters in columns are different (Tukey test, $P<0.05$ ).

the amount of pollen deposited on the stigma in the first visit (53 grains) (table 2). This difference is due to pollen loss by the pollinator during pollen collection and transfer. Similar findings have been made by others with pumpkins, in which honey bees deposited 215 pollen grains in a single visit (Tepedino 1981), and in cucumber (Cucumis sativus), in which 129 pollen grains were placed on the stigma on the first visit, and 33 or fewer grains in subsequent visits (Collison \& Martin, 1979). In contrast, our study indicated that the amount of pollen deposited on the stigma was 7 to 9 times greater when the flowers received two visits compared to one (table 2). Therefore, the amount of pollen transferred in each visit is not constant. Factors such as high pollen concentration and favorable climatic conditions for bee activity and pollinator efficiency influence the amount of pollen transferred (Collison \& Martin 1979).

Pollination and fruit set - Pumpkins required 12 bee visits per flower to transfer enough pollen that it was not limiting to fruit set. According to previous results of this experiment (Vidal et al. 2006), in the period from 39 to 66 days after planting (DAP), the number of male flowers per plant increased from 15 to 34 and female flowers increased from 0.3 to 2.2 flowers. In this period, in which the honey bees started to visit the flowers, the influence of different frequencies of visits on fruit set was evaluated (2, 4, 8 and 12 visits). The percentage of fruits set was highest when flowers received 12 bee visits, with a fruit set of $100 \%$ (table 3 ). There was no difference in the treatments with 2,4 and 8 visits, in which the average of fruit set was 55\% (figure 2). The effect of the number of visits on percentage fruit set was consistent with other studies with several Cucurbit
Table 3. Bee visit duration and fruit set in pumpkin female flowers during different numbers of bee visits in 1997. Average of 20 replicates.

\begin{tabular}{cccc}
\hline $\begin{array}{c}\text { Number of } \\
\text { visits } \\
\text { per flower }\end{array}$ & \multicolumn{2}{c}{ Visit duration (sec) } & Fruit set \\
\cline { 2 - 3 }$(\%)$
\end{tabular}

Means followed by different letters in columns are different ( $n=20$ flowers; Tukey test, $P<0.05$ ).

species (Aldrez 1966, Collison \& Martin 1979, Free 1993, Grewal \& Sidhu, 1979, Hochmuth et al. 1995, Stapleton et al. 2000, Stanghelini et al. 1997).

The success of the pollination depends on pollinator efficiency during the period in which the flowers are viable to receive pollen. Pollen viability of $C$. pepo is higher right after flower opening (around 92\%), and decreases to $75 \%$ at the end of anthesis (Nepi \& Pacini 1993). Therefore, in the data collection period (8h00$10 \mathrm{~h} 00 \mathrm{am})$ the flowers should have had high receptivity, favoring pollination and fertilization.

The average duration of bee visit to the female flower in the period between $8 \mathrm{~h} 00$ and $10 \mathrm{~h} 00$ am was short (18 sec.) when the flower was only visited once. On multiple visits, duration per visit did not vary significantly with the number of visits (table 3), averaged 75 seconds in 1996 and $79 \mathrm{sec}$. in the two experiments in 1997 (tables 2,3 ). This variation is comparable to observations made 

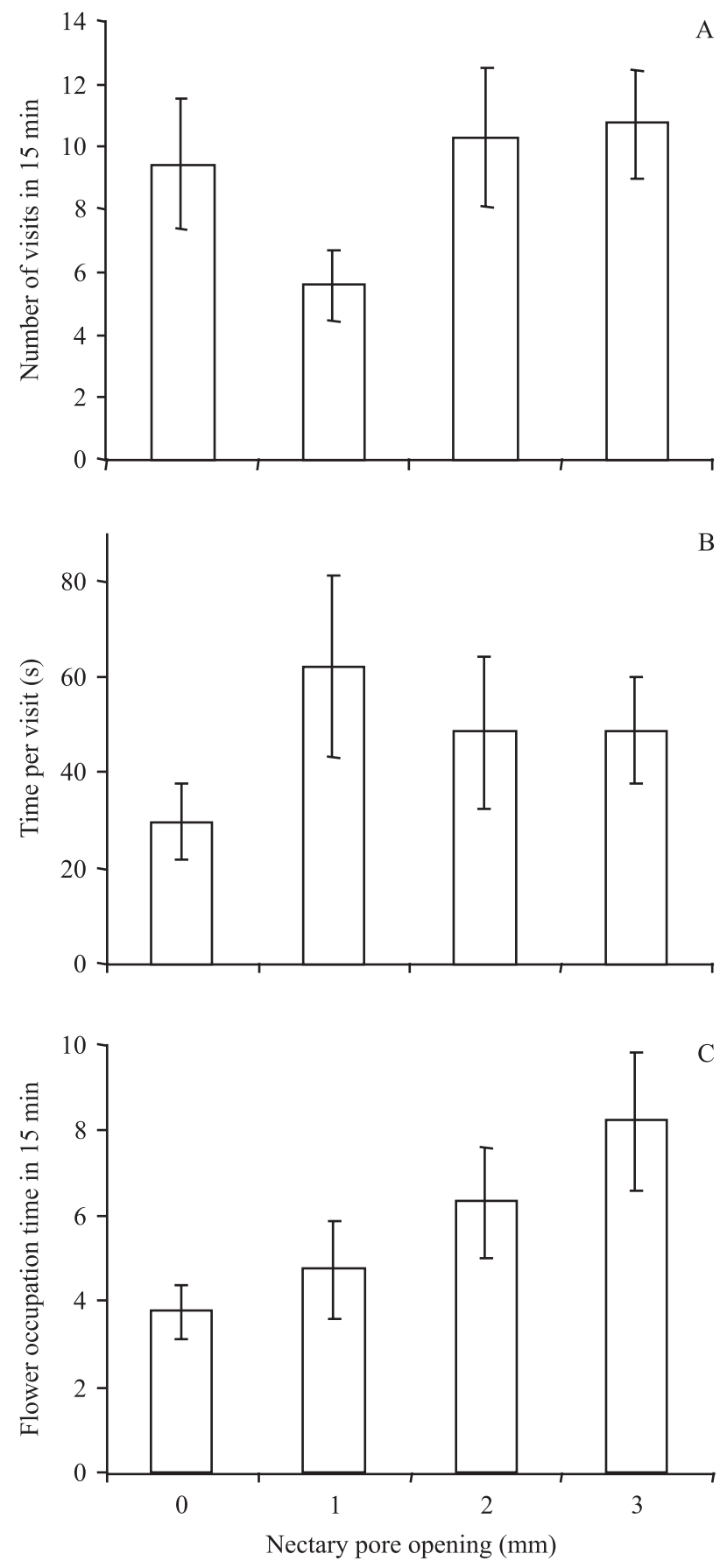

Figure 2. Number of bee visits in 15 minutes (A), duration of each visit (B) and flower occupation time in 15 minutes (C), in male flowers of pumpkin with different degrees of nectary pore opening in 1996. Average of seven flowers. Bars represent standard deviation.

in C. pepo by other authors (Couto et al. 1990, Nepi \& Pacini 1993).

Complete fruit set in pumpkins requires 1500 to 2000 pollen grains per flower (Cady 1993, Masierowska $\&$ Wien 2000). We found that fruit set was maximal with
12 visits, which provided $1,253 \pm 484$ pollen grains (table 2 ). If bee populations provided fewer visits, fruit set would likely be reduced. With 8 visits, when 668 grains were deposited on the stigma (table 2), fruit set was $65 \%$ (table 3 ). The need for many pollen grains per ovule is due to reduction in pollen viability by low temperatures, rains, low activity of the bees and no germinating pollen left on the stigma (Stanley \& Linskens 1974, Nepi \& Pacini 1993).

Many bee visits were necessary because honey bees were relatively inefficient at transferring pollen. On a first visit, a bee would remove about 14,000 grains, of which 1,000 to 4,000 would adhere to the bee's body (figure 1). Of these, only 50 to 200 would be transferred to the stigma of the next female flower visited (table 2). The low pollen deposition on the stigma can be attributed partly to pollen loss when the bees enter and leave a flower. Honey bees usually lose pollen when entering a flower, especially if they come from a male flower that is loaded with pollen. When bees leave the male flower many grains fall to the base of the stamen and corolla. In addition, pollen transfer to the stigma depends on the extent to which the pollen on the bee's body is brushed off by contact with the stigma.

Opening of nectaries and attractiveness - Honey bees visit pumpkin flowers for nectar, as well as for pollen. Therefore it might be possible to increase the attractiveness of flowers by making the nectar easier to access. The attractiveness of flowers to pollinators in the field is generally associated with nectar availability and pollen abundance in the flower (Thorp 1979, Pierre et al. 1996). The influence of the size of the nectary pore opening on the attractiveness of the male flowers was evaluated through: (a) number of visits in 15 minutes of observation (figure 2A), (b) time spent on each visit (figure 2B), and (c) flower occupation time in 15 minutes of observation (figure 2C). In the nectaries with pores, the number of visits in flowers with a $1 \mathrm{~mm}$ pore (6 visits) was significantly smaller than in flowers with pores of 2 and $3 \mathrm{~mm}$ (10 and 11 visits, respectively) (figure 2A). In the flowers without pores the number of visits was similar to the flowers with 2 and $3 \mathrm{~mm}$ pores, however, the time spent in each visit was significantly shorter in those without pores than in flowers with enlarged openings (figures. 3A and 3B). Therefore in the flowers without pores, where the access to the nectar was blocked, the bees stayed about 30 seconds collecting only pollen, while in flowers with openings, bees took more time (48 to $62 \mathrm{~s}$; figure 3B) collecting both pollen and nectar. Previous investigators have confirmed that in addition, 

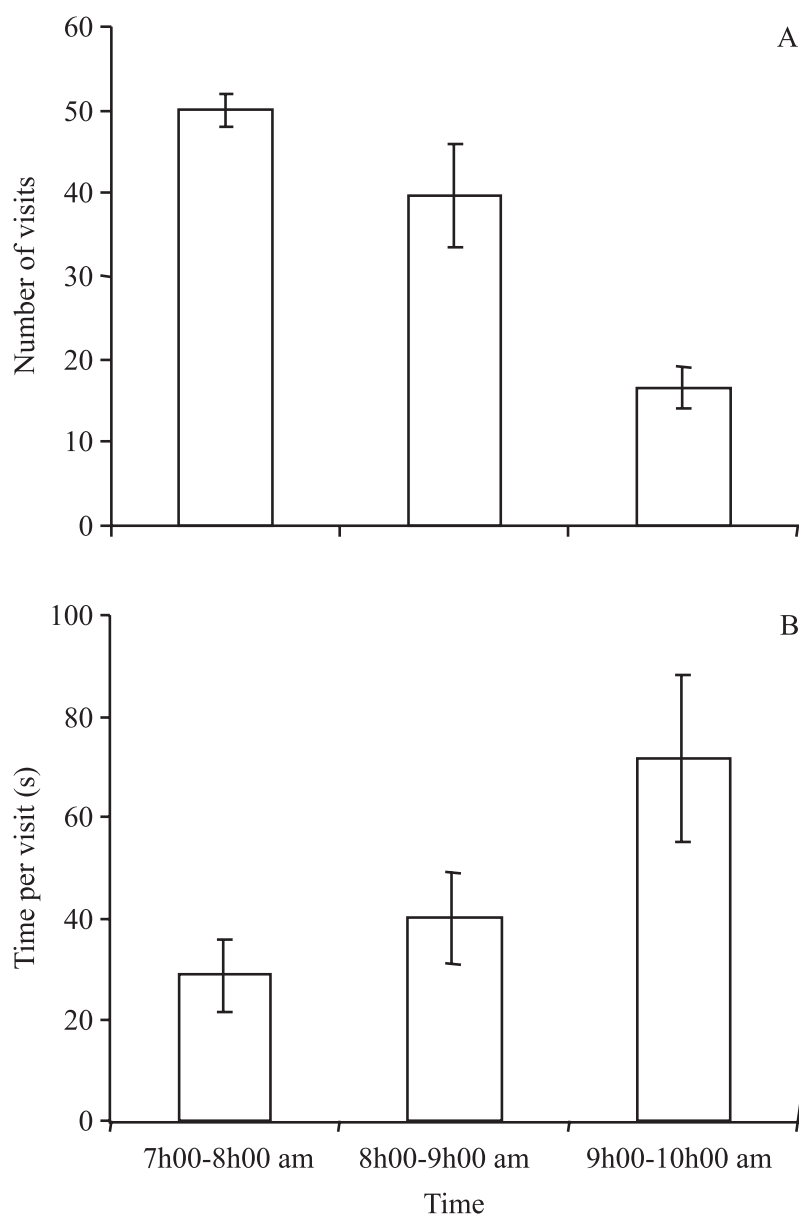

Figure 3. Number of bee visits per flower (A) and duration of each (B), in male flowers of pumpkin in different daytime periods in 1996. Bars represent standard deviation.

the type of sugar, its concentration and the total amount of sugars in the nectar also play a role in visit duration (Wykes 1952, Lepage \& Boch 1968, Crane 1985).

The flower visit time increased with the size of the nectary pore opening (figure 2C). Flowers without pores were visited for only 3.8 minutes per 15 -min observation while the flowers with pores of $3 \mathrm{~mm}$ were visited for 8.2 minutes. Nectar availability prolongs the time spent by pollinators on a particular flower, apparently increasing the probability of pollen deposition and successful pollination (Manetas \& Petropoulou 2000). Considerable variation has been observed among pumpkin varieties in the size of the nectary pore opening and in the form and height of the style in female flowers. These results indicate that selecting for larger pores should result in varieties that increase the pollinators' visits, the amount of pollen gathered and, therefore, fruit set.

The number and duration of honey bee visits varied with the time of day (figure 3). Early in the day (7h00-8h00 am), bees made many short visits. Later, (9h00-10h00 am) visits were less frequent but longer. There were 50 visits of 29 seconds each in the first hour, and 17 visits of 72 seconds in the last hour of the three-hour period (figure 3).

Fruit set in pumpkins is maximized with around 1,200 pollen grains per flower, which is accomplished by 12 honey bee visits during the few hours that the flowers are open. Large nectary openings increase male flowers' attractiveness to pollinators, and can increase visit frequency and pollination success.

Acknowledgements - The authors wish to thank the Department of Fruit and Vegetable Sciences, Cornell University, for Crop and Lab facilities. Thanks also to Carlos Augusto Vidal, Dulce Vidal and Ragendra de Sousa for helping in data collection, and Dr. Thomas Bjorkman for revising assistance. A special gratitude to Alfredo A.C. Alves for field and lab assistance.

\section{References}

ALDREZ, W.C. 1966. Honey bee visit numbers and watermelon pollination. Journal of Economic Entomology 59:28-30.

CADY, S.W. 1993. Pollination and flowering patterns of fieldgrown pumpkin (Cucurbita pepo). PhD dissertation, Cornell University, Ithaca.

COLLISON, C.H. \& MARTIN, E.C. 1979. The relationship of foraging activity to fruit set and shape in the pollination of pickling cucumbers (Cucumis sativus). Agricultural Experimental Station. Special Miscellaneous Publication 1:183-188.

COUTO, R.H., PEREIRA, J.M.S. \& COUTO, L.A. 1990. Estudo da polinização entomófila em Cucurbita pepo (abóbora italiana). Científica 18:21-27.

CRANE, E. 1985. O livro do mel. Editora Nobel, São Paulo.

FREE, J.B. 1993. Insect pollination of crops. Academic Press, San Diego.

GREWAL, G.S. \& SIDHU, A.S. 1979. Note on the role of bees in the pollination of Cucurbita pepo. Indian Journal of Agriculture Science 49:385-388.

HARDER, L.D. 1990. Pollen removal by bumble bees and its implications for pollen dispersal. Ecology 71:1110-1125.

HOCHMUTH, G.J., MAYNARD, D.N., VAVRINA, C.S., STALL, W.M., KUCHAREK, T.A., JOHNSON, F.A. \& TAYLOR. T.G. 1995. Cucurbit production in Florida: cantaloupe, cucumber, muskmelon, pumpkin, squash, watermelon (HS 725). In Vegetable production guide for Florida (SP 170) (G.J. Hochmuth and D.N. Maynard, eds.). University of Florida, Gainesville, p.179-207.

LEPAGE, M. \& BOCH. R. 1968. Pollen lipids attractive to honey bees. Lipids 3:530-534. 
MANETAS, Y. \& PETROPOULOU, Y. 2000. Nectar amount, pollinator visit duration and pollination success in the Mediterranean shrub Cistus creticus. Annals of Botany 86:815-820.

MASIEROWSKA, M. \& WIEN, H. 2000. Flowering, pollination and fruit set of two pumpkin (Cucurbita pepo L.) cultivars under field conditions. Apiacta 35:97-105.

MORSE, R.A. 1994. The new complete guide to beekeeping. The Countryman Press, Woodstock.

MURCIA, C. 1990. Effect of floral morphology and temperature on pollen receipt and removal in Ipomoea trichocarpa. Ecology 71:1098-1109.

NEPI, M. \& PACINI, E. 1993. Pollination, pollen viability and pistil receptivity in Cucurbita pepo. Annals of Botany 72:527-536.

NICODEMO, D., COUTO, R.H.N., MALHEIROS, E.B. \& DE JONG, D. 2009. Honey bee as an effective pollinating agent of pumpkin. Scientia Agricola 66:476-480.

NILSSON, L.A. 1988. The evolution of flowers with deep corolla tubes. Nature 334:147-149.

PIERRE, J., LE GUEN, LE GUEN, J. DELÈGUE, M.H.P., MESQUIDA, MARILLEAU, J.R. \& MORIN, G. 1996. Comparative study of nectar secretion and attractivity to bees of two lines of spring-type faba bean (Vicia faba $\mathrm{L}$ var equina Steudel). Epidologie 27:65-67.

RAGSDALE, N.N. 2007. Vanishing honey bees - colony collapse disorder. Outlooks on Pest Management 28:280-282.

STANGHELLINI, M.S., AMBROSE, J.T. \& SCHULTHEIS, J.R. 1997. The effects of honey bee and bumble bee pollination on fruit set and abortion of cucumber and watermelon. America Bee Journal 137:386-391.
STANLEY, R.G. \& LINSKENS, H.F. 1974. Pollen: biology biochemistry management. Springer-Verlag, New York.

STAPLETON, S.C., WIEN, H.C. \& MORSE, R.A. 2000. Flowering and fruit set of pumpkin cultivars under field conditions. HortSciences 35:1074-1077.

STEPHENSON, A.G., DEVLIN, B. \& HORTON, J.B. 1988. The effects od seed number and prior fruit dominance on the pattern of fruit production in Cucurbita pepo (zucchini squash). Annals of Botany 62: 653-661.

TEPEDINO, V.J. 1981. The pollination efficiency of the squash bee (Peponapis pruinosa) and the honeybee (Apis mellifera) on summer squash (Cucurbita pepo). Journal of Kansas Entomology Society 54: 359-377.

THORP, R.W. 1979. Structural, behavioral, and physiological adaptations of bees (Apoidea) for collecting pollen. Annals of Missouri Botanic Garden 66:788-812.

VIDAL, M.G., DE JONG, D., WIEN, H.C. \& MORSE, R.A. 2006. Nectar and pollen production in pumpkin (Cucurbita pepo L.). Revista Brasileira de Botânica 29:267-273.

WALTERS, S.A. \& TAYLOR, B.H. 2006. Effects of honey bee pollination on pumpkin fruit and seed yield. HortScience 41:370-373.

WIEN, H.C. 1997. The cucurbits: cucumber, melon, squash and pumpkin, In The physiology of vegetable crops (H.C. Wien, ed.). CAB International, Wallingford, p.345-386.

WYKES, J.R. 1952. The influence variations in the supply of carbohydrate on the process of nectar secretion. New Phytologist 51:294-300. 
